\title{
NUTRITIONAL STATUS AND FUCTIONAL STATUS AMONG ELDERLY IN SANTO YOSEF SURABAYA NURSING HOME
}

\author{
Afif $\mathrm{F}$ Wafi $^{1)}$, Hendro Susilo ${ }^{2)}$, Angela S Nariswari ${ }^{3)}$
}

\begin{abstract}
Introduction: Elderly population is prone to the risk of nutritional status problems. The problem of nutritional status in the elderly will affect their condition, such as functional ability to carry out daily activities. Good nutritional status is an important determinant of functional capacity, independence and quality of life of the elderly.

Aim: This research was conducted to find out whether there was a correlation between nutritional status and functional status among elderly in Santo Yosef Surabaya Nursing Home.
\end{abstract}

Methods : This study used an observational analytic study with a cross sectional approach. The sampling technique in this study was purposive sampling. The measuring instrument used was an MMSE questionnaire for assessment of cognitivse function, MNA-SF for assessment of nutritional status and Barthel Index for assessment of functional status. The analysis technique used was the Kendall's Tau c correlation test.

Result : Of the 43 research subjects, 34.9\% suffered from malnutrition, $41.9 \%$ were at risk of malnutrition, and $23.3 \%$ were normal. Functional status data found $2.3 \%$ have total dependence, $20.9 \%$ heavy dependence, $18.6 \%$ moderate dependence, $37.2 \%$ mild dependence, and $20.9 \%$ are independent. The results demonstrated a significant correlation with the strength of a moderate positive correlation between nutritional status and functional status among elderly in Santo Yosef Surabaya Nursing Home $(r=0.42 ; p=0.001)$.

Conclusion: This study shows that there is a significant correlation between nutritional status and functional status.

Keywords : Elderly, nutritional status, functional status

\footnotetext{
1) Student of Faculty of Medicine, Widya Mandala Catholic University Surabaya, Kalisari Selatan 1 Surabaya Email : afiffasialwafi@gmail.com

2) Neurology Department Faculty of Medicine, Widya Mandala Catholic University Surabaya, Kalisari Selatan 1 Surabaya

3) Physiology Department, Faculty of Medicine Widya Mandala Catholic University Surabaya, Kalisari Selata 1 Surabaya
} 


\section{INTRODUCTION}

According to the Law of the Republic of Indonesia Number 13 of 1998 concerning welfare of the elderly, elderly is defined as someone who is aged 60 years and over. The population of elderly in Indonesia is expected to increase every year. This is because of the development in various fields, especially in the health sector $^{(1)}$.

Based on data from the Ministry of Health Republic of Indonesia regarding population projections ${ }^{(2)}$, it is estimated that in 2017 there was 23.66 million elderly people in Indonesia or $9.03 \%$ of the population. It is estimated that the total population of the elderly will increase to 27.0 million in 2020, 33.69 million in 2025, 40.95 million in 2030 and increased to 48.19 million in 2035 .

Along with the increasing number of elderly population, there are also gerontological changes in the health sector. The number of elderly people with all the problems will be greater, more serious and more complex ${ }^{(3)}$. The increasing health problems of the elderly are caused by changes in various organ functions. Therefore, the elderly often suffers from degenerative diseases. Sign and symptoms of the disease in the form of geriatric syndrome which indicates the presence of a physical, psychological or social disorder ${ }^{(4)}$.
According to Stanley ${ }^{(5)}$, the occurrence of the aging process will cause various setbacks in physical, visual and auditory abilities so that the elderly needs help to facilitate their daily activities. In other words, the degenerative process will increase the dependence of the elderly ${ }^{(6)}$.

Health problems in elderly relate to the need for a good quality of life, given the high increase in the incidence of chronic diseases, including neurological and musculoskeletal diseases, as well as reduced multisensory abilities. The concept used to describe a good quality of life is active life expectancy that shows a person's ability to carry out functional activities independently ${ }^{(7)}$.

Functional status describes the concept of quality of life for elderly people in relation to their illness. Assessment of functional status is very important to determine the extent to which somatic complaints in the elderly affect the rehabilitative functions ${ }^{(8)}$. Functional status is an important matter concerning health in elderly. In the elderly the functional status shows whether an elderly person as an individual can still perform his daily functions or not. If there is a disruption of functional status, it means that there is a decrease in the ability to fulfill one's own needs ${ }^{(9)}$.

Based on the facts of the existing research, functional status is closely 
related to nutritional status. Research carried out abroad, according to study which was conducted by Pooneh et $\mathrm{al}^{(10)}$, sarcopenia and frailty in the elderly are the two most common syndromes which result from malnutrition. This can accelerate the decline in functional status. According to Schrader et $\mathrm{al}^{(11)}$, acute illness and morbidity in the elderly will increase the risk of malnutrition so that it has an impact on their functional abilities. The results of the study showed that, as many as $36.6 \%$ of the research subjects were almost independent in carrying out Activity of Daily Living (ADL), 39.0\% needed help and $24.4 \%$ were very dependent. Barthel index scores decreased significantly with worsening nutritional status. Independence in ADL was also found to decrease significantly along with a decrease in nutritional status. For all question items in the Barthel Index, except for 'grooming' and 'bladder control', the proportion of research subjects without limitation decreased followed by an increase in impaired function which parallel with a decrease in nutritional status.

Elderly is one group that is at risk of nutritional problems because along with changes in physical and psychological aspects during the aging process there will also be changes in nutritional needs ${ }^{(5)}$. The problem of nutritional status in elderly will affect various conditions of the elderly such as the ability to carry out daily $\operatorname{activities}^{(12)}$.

Nutritional deficiencies and excess are a problem of nutritional status that is commonly experienced by elderly. If elderly experience malnutrition, and the intake of food consumed does not meet the energy needed, then their ability to do their activity will decrease. Excess nutrition in elderly means that there is an excess of energy in the form of being overweight, resulting in the inability of oneself to carry out physical activities ${ }^{(13)}$.

The World Health Organization (WHO) estimates that in 2015, malnutrition will affect 1 in 6 global populations. In European countries the problem of malnutrition affects more than 30 million citizens ${ }^{(14)}$. Therefore this research was done to examine the nutritional status of the elderly, especially in Indonesia, which is still a developing country.

In Indonesia the prevalence of malnutrition in elderly in 1998 was $7.23 \%$ which increased to $11.56 \%$ in 2001 , while the prevalence of over nutrition was $10.51 \%$ in 1998 and increased to $8.11 \%$ in $2001^{(15)}$. Other data showed in Indonesia, prevalence nutritional status problems in the elderly include malnutrition $3.4 \%$, underweight $28.3 \%$, ideal body weight $42.4 \%$, overweight $6.7 \%$, and obese at $3.4 \%{ }^{(13)}$. 
According to Khongar et al, the condition of malnutrition was often experienced by the elderly. The prevalence of malnutrition in elderly who live in nursing homes or hospitals is greater than in homes $30 \%$ to $60 \%$ compared to $5 \%$ to $10 \%$. Previous research data showed that the condition of nutritional status at the Griya Usia Lanjut Santo Yosef Surabaya showed that most of the residences have risk of malnutrition $62.5 \%$, normal was $37.5 \%$ and malnutrition was $0 \%{ }^{(16)}$. While the condition of functional status in Griya Usia Lanjut Santo Yosef Surabaya, was found to be $58.6 \%$ mild dependence, and $20.7 \%$ for both moderate dependence and heavy dependence ${ }^{(17)}$.

Based on the description above, this problem underlies the importance of research to find out about the correlation between nutritional status and functional status in the elderly at the Griya Usia Lanjut Saint Joseph Surabaya.

\section{METHODS}

This study used an observational analytic study with a cross sectional approach. The purpose of this study was to analyze the correlation of nutritional status and functional status in the elderly in the Griya Usia Lanjut Saint Joseph Surabaya. The subjects in this study were elderly at the Griya Usia Lanjut Santo Yosef Surabaya who met the inclusion and exclusion criteria. The sampling technique in this study was purposive sampling.

In this study the measuring instruments used were MMSE questionnaire for the assessment of cognitive function, MNASF for assessment of nutritional status and the Barthel Index for assessment of functional status. All data were analyzed using the Statistical Package for the Social Sciences (SPSS) program. The analysis techniques used were the Kendall's Tau c correlation test.

\section{RESULT}

The total population was 163 respondents, with details 63 respondents unwilling to take part and 100 respondents were willing to take part in this study. Data collection began with MMSE assessment, obtained 43 respondents who met the inclusion and exclusion criteria of the researcher. This number has met the minimum sample needed in accordance with the sample size formula for correlation study that is at least 32 people so that all existing samples were taken.

The collected data then was analyzed statistically. Analysis of the subjects characteristics included the age group, gender, nutritional status and functional status. The results of the analysis of the basic subject characteristics are showed in the table below: 
Table 1 Basic Characteristics of $\begin{array}{llllll}\text { Total } & 15(100) & 18(100) & 10(100) & 43(100)\end{array}$

Respondents

\begin{tabular}{lcc}
\hline \multicolumn{1}{c}{ Basic Characteristics } & n & \% \\
\hline Age group & & \\
Middle Age (45-59 years) & 3 & 7 \\
Elderly (60-74 years) & 15 & 34,9 \\
Old (75-90 years) & 25 & 58,1 \\
Gender & & \\
Man & 19 & 44,2 \\
$\quad$ Woman & 24 & 55,8 \\
Nutritional Status (MNA- & & \\
SF) & & \\
Malnutrition & 15 & 34,9 \\
At risk of malnutrition & 18 & 41,9 \\
Normal & 10 & 23,2 \\
Functional Status & & \\
Total dependency & 1 & 2,4 \\
Weight Dependence & 9 & 20,9 \\
Moderate dependency & 8 & 18,6 \\
Mild dependence & 9 & 20,9 \\
Independent & & \\
\hline
\end{tabular}

Table 2 Distribution of Nutritional Status Data on Elderly Functional Status in the Griya Usia Lanjut Saint Joseph Surabaya in July 2018.

\begin{tabular}{ccccc}
\hline & \multicolumn{4}{c}{ Nutritional status } \\
\cline { 2 - 5 } Functional & $\begin{array}{c}\text { Malnut } \\
\text { Status }\end{array}$ & $\begin{array}{c}\text { At risk of } \\
\text { malnutrit } \\
\text { ion }\end{array}$ & Normal & Total \\
\cline { 2 - 5 } & $\mathrm{n}(\%)$ & $\mathrm{n}(\%)$ & $\mathrm{n}(\%)$ & $\mathrm{n}(\%)$ \\
\hline Total & & & & \\
dependency & $1(6,6)$ & $0(0)$ & $0(0)$ & $1(2,4)$ \\
Weight & & & & \\
$\begin{array}{c}\text { Dependence } \\
\text { Moderate }\end{array}$ & $6(40)$ & $1(5,5)$ & $2(20)$ & $9(20,9)$ \\
dependency & $4(26,7)$ & $3(16,7)$ & $1(10)$ & $8(18,6)$ \\
Mild & & & & \\
dependence & $4(26,7)$ & $9(50)$ & $3(30)$ & $16(37,2)$ \\
Independent & $0(0)$ & $5(27,8)$ & $4(40)$ & $9(20,9)$ \\
\hline
\end{tabular}

Based on the data obtained, cross tabulation was carried out between the independent variables (nutritional status) and the dependent variable (functional status) using the Kendall's Tau c correlation test. The value of $\alpha$ is set at 0.05 so that it is considered significant if $p$ $<0.05$.

Table 3 Analysis of Correlation of Nutritional Status and Functional Status in the Elderly at the Griya Usia Lanjut Saint Joseph Surabaya in 2018.

\begin{tabular}{clr}
\hline $\begin{array}{c}\text { Kendall's } \\
\text { Tau c }\end{array}$ & $\begin{array}{r}\text { Nutritional } \\
\text { status }\end{array}$ \\
\hline \multirow{2}{*}{ Functional } & Significance (p) & 0,001 \\
Status & Correlation coefficient (r) & 0,42 \\
& $\mathrm{~N}$ & 43 \\
\hline
\end{tabular}

In accordance with the hypothesis in this study, a correlation analysis of nutritional status and functional status was carried out using the Kendall's Tau c statistical test as in the table above. $P$ value was 0.001 or smaller than $\alpha=0.05$ which indicates that there is a significant correlation between nutritional status and functional status $(\mathrm{p}=0.001 ; \mathrm{p}<0.05)$.

The value of the correlation coefficient (r) in this study is 0.42 , therefore it can be concluded that there is a moderate correlation between nutritional status and functional status with a positive 
relationship direction. This shows the existence of a relationship that is directly proportional between the dependent and independent variables. Therefore, if the an elderly has a low nutritional status, their functional status will also be low.

\section{DISCUSSION}

The basic characteristics of the research subjects in the form of nutritional status differed from the data of previous research conducted by Prijanto ${ }^{(16)}$ in 2015 at the Griya Usia Lanjut Saint Joseph Surabaya. The data about nutritional status found a normal nutritional status of $37.5 \%$, the risk of malnutrition was $62.5 \%$ and malnutrition was $0 \%$. This is different from this recent study which found a normal nutritional status of $23.2 \%$, at risk of malnutrition $41.9 \%$ and malnutrition $34.9 \%$. This shows the number of normal nutritional status decreases and the malnutrition of elderly increased at the Griya Usia Lanjut Saint Joseph Surabaya.

The basic characteristics of the research subject in functional status are the same as the data of previous research conducted by Jansen ${ }^{(17)}$ in 2017 at the Griya Usia Lanjut Saint Joseph Surabaya. The research shows that the highest prevalence is found in functional status with mild dependence of $58.6 \%$. This is the same as this recent study which found that the highest prevalence was found in functional status with mild dependence of $37.2 \%$. This is likely due to physical decline in the elderly. That has an impact on decreasing the level of independence of the elderly in carrying out daily activities.

In accordance with the results that shows a significant correlation between nutritional status and functional status in elderly. This is in line with the results of other studies that also found a significant relationship between nutritional status and functional status. According to the results of a study conducted by Villafañe et al ${ }^{(18)}$ in 2017, there was a significant relationship between nutritional status in elderly based on the Mini Nutritional Assessment Short Form and functional status based on the Barthel Index ( $p>$ 0.001). This study using same method to get the data. However, the sample size in that study totaled more than 344 subjects. The difference in the number of samples allows for more significant results to be obtained. The results of the study showed that subjects with better functional status (Barthel Index 45-100) tended to have normal nutritional status (MNA-SF 12-14). In contrast, subjects with poor functional status (Barthel Index 0-44) were more likely to be malnourished or at risk of malnourishment (MNA-SF 0-11).

Aging is associated with a decrease in functional status and an increased risk of malnutrition. Studies have shown that 
around $25-45 \%$ of the living community of the elderly will be malnourished or at risk of malnutrition. In elderly, nutritional status has been shown to be associated with functional dependence. Elderly people who are malnourished will increase the frequency and length of stay in hospital, increase the risk of depression, cognitive impairment, poor quality of life to mortality ${ }^{(19)}$.

Nutritional status is closely related to functional status. Malnutrition results in reduced autonomic functions, such as preparing food so that food intake will decrease. Functional status disorders increase vulnerability that affects food consumption patterns as well as the quality and quantity of food consumed ${ }^{(18)}$.

Malnutrition and decreased functional status are two important factors that contribute to the loss of independence in elderly ${ }^{(20)}$. Malnutrition has a direct impact on muscle and nervous system activity. Therefore, malnutrition can cause muscle weakness and the brain's inability to deal with sensorimotor and cognitive related functions ${ }^{(18)}$. Malnutrition characterized by a decrease in body weight, mass and muscle strength is considered as an etiological factor in the development of sarcopenia and frailty in the elderly ${ }^{(20)}$. Sarcopenia and frailty are two geriatric syndromes that foster functional disorders in elderly ${ }^{(11)}$.
Decreasing nutritional status is considered the first event that can lead to increased dependency of elderly. Thus, there is a possibility that decrease in food intake can lead to reduced independence in carrying out daily activities, thinning of muscle mass, and the occurrence of malnutrition $^{(21)}$. The loss of physical capacity will occur along with reduced mobility and limitations in carrying out daily activities such as shopping, cooking and eating so that it will have an impact on nutritional status ${ }^{(20)}$.

Good nutritional status is an important determinant of functional capacity, independence, and quality of life for the elderly. However, nutritional status can easily deteriorate with age because of the process of physiological, psychological, social, and economic changes. Therefore, to improve the quality of life of the elderly, more attention needs to be paid in nutritional status which will have a direct impact on the level of independence of the elderly in carrying out daily activities ${ }^{(22)}$.

\section{CONCLUSION}

The results of this study indicate that there is a significant correlation with the moderate positive strength of correlation between nutritional status and functional status in elderly at the Griya Usia Lanjut Saint Joseph Surabaya. This suggests that subjects who have low nutritional status 
will tend to have low functional status as well. The nutritional status of elderly in Griya Usia Lanjut Santo Yosef Surabaya was dominated by the category at risk of malnutrition and functional status dominated by mild dependency.

If the nutritional status of the elderly is good, it will have an impact on the reduced burden of dependence on the family and the country. In addition, increase in nutritional status of the elderly will also have an impact on dependency, decreased length of stay in hospital, decreased risk of depression, decreased cognitive impairment, increased independence, improved quality of life and prevention of elderly morbidity.

\section{REFERENCES}

1. Kementrian Kesehatan RI. Situasi dan Analisis Lanjut Usia. InfoDATIN Pusat Data dan Informasi (2014).

2. Kementrian Kesehatan RI. Analisis Lansia di Indonesia. 8 (2017).

3. Fatmah. Gizi Usia Lanjut. (Penerbit Erlangga, 2010).

4. Darmojo, B. R. Geriatri: Ilmu Kesehatan Usia Lanjut. (Fakultas Kedokteran Universitas Indonesia, 2015).

5. Stanley, M. \& Beare, P. G. Buku Ajar Keperawatan Gerontik. (Penerbit Buku Kedokteran EGC, 2007).

6. Nugroho. Keperawatan Gerontologik. (Buku Kedokteran EGC, 2008).

7. Frontera, W. R. De Lisa's Physical Medicine \& Rehabilitation Principles and Practice. in 1545-1586 (Lippincot Williams and Kilkins, 2010).

8. Dewi, S. R. Buku Ajar Keperawatan Gerontologik. (Deepublish, 2014).
9. Abrams, W. B. \& Berkow, R. The Merck Manual Geriatrics. (Binarupa Aksara, 2013).

10. Khongar, P. D., Sadat, S. Z., ShabBidar, S. \& Neyestani, T. R. Relationships Between Mini Nutritional Assessment and Functional Status in Elderly Iranian People Living in Nursing Homes. 1, 149-156 (2015).

11. Schrader, E. et al. Nutritional Status According to Mini Nutritional Assessment is Related to Functional Status in Geriatric Patients Independent of Health Status. 18, 257-263 (2013).

12. Ukegbu, U., Maselko, J., Malhotra, R., Perera, B. \& Ostbye, T. Correlates of Hand Grip Strength and Activities of Daily Living in Elderly Sri Lankas. 1800-1801 (2014).

13. Martono, H. H. \& Pranarka, K. Buku Ajar Boedhi-Darmojo: Geriatri (Ilmu Kesehatan Usia Lanjut). (Balai Penerbit Universitas Indonesia, 2010).

14. Nestle. Malnutrition in The Older Adult. Nestle Nutr. 1-4 (2010).

15. Saniawan. Nutritional Status of Elderly at Banjar Paang Tebel in North Peguyangan Village 3rd Public Health Centre Work Territorial in North Denpasar 2007. (2009).

16. Prijanto, S. A. Hubungan Status Gizi dengan Kemampuan Mobilitas Fungsional pada Lansia di Griya Usia Lanjut St. Yosef Surabaya. (Universitas Katolik Widya Mandala Surabaya, 2015).

17. Jansen. Hubungan Status Fungsional dengan Inkontinensia Urin pada Usia Lanjut di Griya Usia Lanjut Santo Yosef Surabaya. (Universitas Katolik Widya Mandala Surabaya, 2017).

18. Villafañe, J. H. et al. Association between malnutrition and Barthel Index in a cohort of hospitalized older adults article information. J. Phys. Ther. Sci. 28, 607-612 (2016).

19. Lee, L. \& Tsai, A. C. Mini Nutritional Assessment Predicts Functional 
Decline of Elderly Taiwanese : Result of a Population-Representative Sample. 1707-1713 (2012). doi:10.1017/S0007114511004880

20. Kiesswetter, E. et al. Malnutrition is Related to Functional Impairment in Older Adults Receiving Home Care. 17, (2013).

21. Souza, L. B. De, Papini, S. J. \& Corrente, J. E. Relationship between Nutritional Status and Functional Capacity for Older People. 1090-1097 (2015).

22. Sugiura, Y., Tanimoto, Y., Imbe, A., Inaba, Y. \& Sakai, S. Association Between Functional Capacity Decline and Nutritional Status Based on The Nutrition Screening Initiative Checklist: A 2- Year Cohort Study of Japanese Community-Dwelling Elderly. $\quad 1-10 \quad$ (2016). doi:10.1371/journal.pone.0166037 